\title{
1. Economic and monetary union
}

\subsection{THE FIRST STEPS TOWARDS ECONOMIC AND MONETARY UNION}

As is well known, the European Economic Community (EEC) was set up with the main aim of creating a customs union and a common market based on the free movement of goods, people, services and capital. Additionally, a few policies were established (on competition, agriculture and transport) that were clearly destined to have a significant impact on Member States' economic policies. Monetary issues were initially entirely outside the scope of the EEC, also because the recently established Bretton Woods system seemed to sufficiently ensure currency stability. Before long, however, it became clear that that was not the case. Indeed, towards the end of the 1960s, the Bretton Woods system started showing signs of crisis, with Europe going through some serious monetary turbulence - particularly in France and Germany. And this turbulence - among its many potentially negative consequences - risked negating the effectiveness of the price support schemes envisaged under the Common Agricultural Policy, as farmers were exposed to serious currency risks. It was against this historical backdrop - when the EEC's transitional period was drawing to a close and customs duties were lifted - that reference was first made to establishing an economic and monetary union.

The Vice-President of the European Commission at the time, Raymond Barre, drafted a Memorandum on the Co-ordination of Economic Policies and Monetary Cooperation ${ }^{1}$ and submitted it to the Council of Ministers on 12 February 1969. In his memorandum, Barre recommended: (i) close coordination of Member States' short-term economic policies; (ii) convergence of Member States' medium-term economic policy aims; and (iii) creation of "machinery" in the Community for monetary cooperation through short- and medium-term measures.

1 Commission Memorandum to the Council on the Coordination of Economic Policies and Monetary Cooperation within the Community (12 February 1969), 2 Bulletin of the European Communities 3 (Supp. 3 1969). 
Barre's plan was approved by the Council in July $1969,{ }^{2}$ and it was the centre of discussion at the summit held in The Hague on 1 and 2 December of that same year - a summit that would come to define a new, ambitious goal of European integration. Indeed, the final communiqué made it expressly clear:

[The Heads of State or Government] reaffirmed their readiness to expedite the further action needed to strengthen the Community and promote its development into an economic union. They are of the opinion that the integration process should result in a Community of stability and growth. To this end they agreed that within the Council [...] a plan in stages will be worked out during 1970 with a view to the creation of an economic and monetary union. ${ }^{3}$

The Council of Ministers of 6 March 1970 took the first steps in implementing the plan by appointing a group of experts - presided over by Pierre Werner, Luxembourg's prime minister and minister of finance - to draw up a report on the realisation by stages of economic and monetary union. ${ }^{4}$ The group immediately saw a clash between two factions: those who believed that monetary unification was to be achieved by gradually reducing fluctuations in exchange rates, and those who, on the contrary, believed that first greater convergence of economic policies was needed. In its final report, dated 8 October 1970, ${ }^{5}$ the group predicted that within a decade Europe would be able to achieve "the total and irreversible convertibility of currencies, the elimination of margins of fluctuation in exchange rates, [and] the irrevocable fixing of parity rates [...]". These objectives were to be achieved in three stages, which were to include the liberation of movements of capital, the integration of financial markets, the elimination of margins of fluctuation in Member States' currencies and, lastly, the fixing of parity rates.

These three stages were quite similar to those outlined almost 20 years later in the Delors Plan, ${ }^{6}$ with the difference being that the Werner Plan did not envisage the adoption of a single currency or the creation of a central bank but only the irrevocable fixing of exchange rates and alignment of monetary policies. In hindsight, these measures would have likely proved insufficient; nonetheless, as commentators would later point out, the Werner Report shined an early spotlight on the fundamental role of fiscal and structural policies in a monetary union - and on the potential problems that could arise if those pol-

2 Council Decision 69/227/EEC of 17 July 1969 on coordination of the short-term economic policies of the Member States, 1969 O.J. ENG. SPEC. ED. 350.

33 Bulletin of the European Communities, No 11, at 15 (1970).

4 Council Decision of 6 March 1970 on the procedure for economic and monetary cooperation, 1971 J.O. (L 59) 44.

3 Bulletin of the European Communities, No 11 (1970).

6 See section 1.3 below. 
icies were not appropriately coordinated. Indeed, seen from this perspective, it was a harbinger of the problems that would erupt onto the scene decades later with the sovereign debt crisis.

\subsection{FROM THE "SNAKE IN THE TUNNEL" TO THE EUROPEAN MONETARY SYSTEM}

The Council approved the Werner Plan and, on 22 March 1971, passed a resolution $^{7}$ in which it indicated the short-term measures needed to move along the path indicated in the plan. A variety of measures were proposed, but two stood out: the progressive reduction in margins of fluctuation between currencies and the creation of a European Monetary Cooperation Fund. ${ }^{8}$

The goal of reducing fluctuation between currencies was soon put to the test: an international monetary crisis struck foreign exchange markets during those same months, culminating with the United States government's infamous decision to suspend the convertibility of dollars into gold. Major negotiations ensued, both at a European and international level, and in 1972 the Council adopted a resolution whereby the margin of fluctuation for European currencies was to be limited to 2.25\%. ${ }^{9}$ The Paris summit of 24 April 1972 marked the official beginning of what was known as the "snake in the tunnel" - a system that intended to limit the fluctuation of European currencies within lower margins than the maximum limit of fluctuation allowed for the dollar. To ensure that these limits were respected, central banks had to carry out marginal interventions in dollars or in EEC currencies (as the case may be) and, when necessary, grant each other lines of credit. However, the system was soon thrown into crisis: currency markets were extremely turbulent in those years, and the snake in the tunnel was unable to contend with currency speculation let alone impose greater alignment of monetary and economic policies. It thus lost most of its members.

Nonetheless, the prospect of an economic and monetary union in Europe did not lose steam: several reports came out in the years that followed, each of which examined how to better build a common European home. It started

7 Resolution of the Council and of the Representatives of the Governments of the Member States of 22 March 1971 on the attainment by stages of economic and monetary union in the Community, 1971 J.O. (C 28) 1.

Regulation (EEC) No 907/73 of the Council of 3 April 1973 establishing a European Monetary Cooperation Fund, 1973 O.J. (L 89) 2.

9 Resolution of the Council and of the Representatives of the Governments of the Member States of 21 March 1972 on the application of the Resolution of 22 March 1971 on the attainment by stages of economic and monetary union in the Community, 1972 J.O. (C 38) 3. 
with the Marjolin Report (8 March 1975) ${ }^{10}$ and continued with the Tindemans Report (29 December 1975), ${ }^{11}$ which for the first time spoke of a two-speed Europe. The MacDougall Report (April 1977) ${ }^{12}$ then suggested that increased integration and the establishment of a monetary union would require a federal budget (ranging from $2-2.5 \%$ to $25 \%$ of GDP, depending on whether it was to become a full federal Union). Finally, in 1977, the newly appointed president of the European Commission, Roy Jenkins, relaunched the idea of economic and monetary union. ${ }^{13}$

At the European Council's Bremen summit the following year (6-7 July 1978), France and West Germany proposed a relaunch of monetary cooperation through the creation of a European Monetary System (EMS). The proposal was then adopted by the European Council in Brussels on 4-5 December, ${ }^{14}$ which passed a resolution on the establishment of the EMS (to enter into force on 13 March 1979). All Member States participated in the EMS except for the United Kingdom. Essentially, the EMS was an agreement on fixed - but adjustable - exchange rates determined based on the European currency unit (ECU), which itself was an accounting unit calculated based on the weighted average of EMS currencies. EMS members agreed on fixed bilateral exchange rates, and the maximum fluctuation band allowed was $2.25 \%$ - except for Italy, which was granted a wider band of $6 \%$ (to be reduced as soon as possible). Under the EMS, Member State governments were to intervene if their currency went over the established fluctuation threshold - and intervention included making use of facilities granted by other central banks or other Community credit mechanisms. Overall, the EMS was successful: it led to greater coor-

10 The report was drawn up by a study group called "Economic and Monetary Union 1980", made up of experts from around Europe and chaired by Robert Marjolin, former Vice-President of the Commission. It was published in 8 BULLETIN OF THE European Communities, No 4, at 29 (1975).

11 The report was drawn up by Leo Tindemans, Prime Minister of Belgium, at the request of the European Council. It was published in BulLETIN OF THE EUROPEAN Communities (Supp. 1, 1976).

12 The report was drawn up by a group of independent economists - chaired by Sir Donald MacDougall - set up by the Commission to examine the future role of public finance in the European Community. See Commission of the European Communities, Report of the Study Group on the Role of Public Finance in European INTEGRATION (April 1977), https://ec.europa.eu/archives/emu_history/documentation/ chapter8/19770401en73macdougallrepvol1.pdf.

13 Speech to the European Parliament, 10 Bulletin of THE European Communities, No 2, at 8 (1977).

14 Resolution of the European Council of 5 December 1978 on the establishment of the European Monetary System (EMS) and related matters, Annex 1 to the Conclusions of the Presidency of the European Council, Brussels, 11 Bulletin of the European Communities, No 12, at 10 (1978). 
dination of monetary policies and helped limit currency volatility. However, although this system was envisioned as a step towards greater European integration, it was entrusted to central banks and national governments - and thus remained outside the EEC's institutional framework.

\subsection{COMPLETING THE INTERNAL MARKET AND THE DELORS REPORT}

In 1985, the Commission famously published a White Paper in which it proposed completing the internal market by the end of 1992 - a goal that entailed, among other things, the elimination of all the remaining physical, technical and fiscal barriers described in the White Paper. ${ }^{15}$ Although the EMS was not part of the overall internal market project, it was, conceptually, a prerequisite for its completion. ${ }^{16}$

That was followed by a significant revision to the Treaty establishing the European Economic Community (TEEC) in the form of the Single European Act (SEA), which was signed on 17 and 28 February 1986. Though the SEA did not set out to address monetary union, it did mention (in its preamble) the objective of economic and monetary union, the creation of the EMS and the measures adopted to implement monetary cooperation. ${ }^{17}$ Furthermore, Art. 20 envisaged the insertion of a new Chapter 1 in the TEEC, to be entitled "Co-operation in economic and monetary policy (economic and monetary

15 Completing the Internal Market: White Paper from the Commission to the European Council, COM (1985) 310 final (28-29 June 1985).

16 See Commission of the European Communities, Europe 1992, The Overall Challenge, SEC (88) 524 final (which summarises Paolo Cecchini's comprehensive enquiry, drawn up at the request of the Commission, into the likely economic impact of completing the single market). In this document, the Commission clearly stated that " $[\mathrm{r}]$ emoving the barriers between financial markets and fully liberalising capital movements will increase the risk of exchange rate instability. This must be countered by increased monetary cooperation through a strengthened EMS".

17 Specifically, the preamble reads as follows:

WHEREAS as their Conference in Paris from 19 to 21 October 1972 the Heads of State or of Government approved the objective of the progressive realization of Economic and Monetary Union,

HAVING REGARD to the Annex to the conclusions of the Presidency of the European Council in Bremen on 6 and 7 July 1978 and the resolution of the European Council in Brussels on 5 December 1978 on the introduction of the European Monetary System (EMS) and related questions, and noting that in accordance with that Resolution, the Community and the Central Banks of the Member States have taken a number of measures intended to implement monetary cooperation. 
union)". And Art. $102 \mathrm{a}^{18}$ required Member States to cooperate in accordance with the objectives of Art. 104 (i.e., equilibrium of the balance of payments, maintaining confidence in currency, and ensuring a high level of employment and stability of prices) while taking account of the experience gained within the framework of the EMS. It was true that the measures taken by Member States to implement economic and monetary cooperation came out of the intergovernmental decision-making method and thus remained outside the EEC's institutional framework; but this marked the first time that: (i) economic and monetary cooperation was mentioned in the Treaty; and (ii) the convergence of economic and monetary policies was acknowledged as being essential to the EEC's further growth. Any institutional amendments would require an intergovernmental conference to be convened in accordance with Art. $236 .{ }^{19}$

This enthusiasm for the completion of the internal market breathed new life into the idea of monetary union. Indeed, the multitude of currencies combined with fluctuating exchange rates seemed destined to continue to lead to high transaction costs - and any benefits to be gained from the completion of the internal market would be significantly limited as long as transaction costs stayed high.

The European Council met against this backdrop at the Hanover summit of 27-28 June 1988, ${ }^{20}$ during which it: (i) recalled that Member States had

18 Art. 102a read as follows:

1. In order to ensure the convergence of economic and monetary policies which is necessary for the further development of the Community, Member States shall co-operate in accordance with the objectives of Article 104. In so doing, they shall take account of the experience acquired in co-operation within the framework of the European Monetary System (EMS) and developing the ECU, and shall respect existing powers in this field.

2. In so far as further development in the field of economic and monetary policy necessitates institutional changes, the provisions of Article 236 shall be applicable. The Monetary Committee and the Committee of Governors of the Central Banks shall also be consulted regarding institutional changes in the monetary area.

19 Art. 236 of the TEEC read as follows:

The Government of any Member State or the Commission may submit to the Council proposals for the revision of this Treaty.

If the Council, after consulting the Assembly and, where appropriate, the Commission, expresses an opinion in favour of the calling of a conference of representatives of the Governments of the Member States, such conference shall be convened by the President of the Council for the purpose of determining in common agreement the amendments to be made to this Treaty.

Such amendments shall enter into force after being ratified by all Member States in accordance with their respective constitutional rules.

20 Conclusions of the Presidency of the European Council, Hanover, 27-28 June 1988 (SN 2683/4/88), 21 Bulletin of the European Communities, No 6, at 164 (1988). 
confirmed their objective of the progressive realisation of economic and monetary union by adopting the SEA; and (ii) appointed a committee to study how to achieve economic and monetary union. The committee was to be chaired by Jacques Delors, President of the European Commission; members were to include the governors of Member States' central banks (in addition to the Director-General of the Bank of International Settlements and some other experts). The committee was expected to submit a report on how to achieve progressive economic and monetary union at the European Council summit scheduled for June 1989 in Madrid.

That report (which came to be known as the "Delors Report") ${ }^{21}$ was published on 17 April 1989. It reached essentially the same conclusion as that of the Werner Report, i.e., that the realisation of a monetary union would require: (i) the irreversible convertibility of currencies; (ii) the total liberalisation of capital transactions and the complete integration of banking and other financial markets; and (iii) the elimination of margins of fluctuation between currencies and the irrevocable locking of exchange rate parities. According to Delors though perhaps he was being overly optimistic - the first two conditions had already been or were soon to be met; the key point, then, was to lock exchange rate parities. ${ }^{22}$ But that would not be enough. The next step in the Community's process of monetary unification was to adopt a single currency, which would clearly also entail the granting of monetary powers to new Community institutions.

Economic union - which remained the ultimate objective - was to be based on the following four pillars:

(i) the internal market;

(ii) competition policy;

(iii) common policies aimed at structural change and regional development; and

(iv) macroeconomic policy coordination, including binding rules for budgetary policies.

${ }^{21}$ Committee for the Study of Economic and Monetary Union (Jacques Delors, Chairman), Report on ECONOMIC AND MONETARy Union in the European Community (17 April 1989), https://ec.europa.eu/economy_finance/publications/ pages/publication6161_en.pdf.

22 According to the "trilemma" economic decision-making theory (credited to the independent studies carried out by Robert Mundell and Marcus Fleming in the 1960s), it is impossible to pursue capital mobility, fixed exchange rates and independent monetary policy all at the same time. Thus, monetary policy independence was to be ruled out. 
Obviously, a balance would have to be struck - not only between monetary policies and economic policies but also between European-level policies and national policies. Indeed, the adoption of a single currency would prevent Member States from using exchange rate adjustments to correct imbalances in their balance of payments or other economic problems. For this very reason, the proposed monetary measures would have to be accompanied by the economic measures described above.

In a nutshell, the Delors Report concluded that economic and monetary union was achievable in three stages that would entail the gradual passage from closer economic and monetary coordination to a single currency, the creation of an independent European Central Bank (ECB) and a European System of Central Banks (ESCB), and the imposition of constraints on the size and financing of national budget deficits.

More specifically, the first stage (to be carried out between 1990 and 1994) envisaged the completion of the internal market and the removal of barriers standing in the way of further financial integration (essentially, all financial instruments would have to be able to circulate freely, and banking, securities and insurance services would be freely offered throughout the Community).

The second stage (to be carried out between 1994 and 1999) would begin once a new Treaty had come into force. It entailed setting up the structure of the economic and monetary union and establishing the institutions that would preside over it. This stage was to be seen as a sort of "training process" in the transition to economic and monetary union; just like the first stage, it also envisaged measures to be taken on both an economic level (i.e., to consolidate the internal market, evaluate the performance of structural and regional policies, and strengthen the convergence of macroeconomic policies) and a monetary level. The monetary measures included the setting-up of the ESCB, which would gradually take over decision-making power from the national central banks.

The final stage would begin by irreversibly locking exchange rates and transferring the relevant monetary competences to Community institutions. Eventually, national currencies would be replaced by a single currency. This stage also envisaged numerous economic measures, including the conferral of authority on the Council of Ministers - together with the European Parliament - to take directly enforceable decisions on national budgets as needed in order to prevent imbalances that might threaten monetary stability.

The report concluded by stating that all of this could only be achieved if a new Treaty was adopted, as only then would Europe have the legal basis needed to ensure coordinated, uniform progress from both an economic and monetary point of view. 


\subsection{THE MAASTRICHT TREATY}

In June of 1989, the European Council met in Madrid ${ }^{23}$ and began to give shape to the measures indicated in the Delors Report. Specifically, the European Council resolved that the first stage would begin on 1 July 1990 with the much-awaited abolition of barriers to the free movement of capital. The fall of the Berlin Wall accelerated the process: François Mitterand and Helmut Kohl reached an understanding whereby German reunification would occur in exchange for a speedier adoption of a single currency. In 1991, two intergovernmental conferences were held simultaneously to amend the Treaty of Rome (one on economic and monetary union, the other on political union). This all led up to the Maastricht Treaty, which was signed on 7 February 1992 and came into effect on 1 November 1993. ${ }^{24}$

The new Treaty made it clear right from the recitals that its signatories intended to strengthen the convergence of their economies and establish an economic and monetary union that included a single currency. ${ }^{25}$ This point was made again in the new Art. 2 of the Treaty establishing the European Community (TEC), wherein the Community's objectives were described as follows:

The Community shall have as its task, by establishing a common market and an economic and monetary union and by implementing the common policies or activities referred to in Articles 3 and 3a, to promote throughout the Community a harmonious and balanced development of economic activities, sustainable and non-inflationary growth respecting the environment, a high degree of convergence of economic performance, a high level of employment and of social protection, the raising of the standard of living and quality of life, and economic and social cohesion and solidarity among Member States.

The new Art. $3 \mathrm{a}^{26}$ completed the picture by providing for an economic policy "based on the close coordination of Member States' economic policies". As to monetary policy, the new Treaty envisaged the stages mapped out in the Delors

23 Madrid European Council, 26-27 June 1989, Presidency Conclusions, 22 Bulletin of the European Communities, No 6, at 8 (1989).

24 Treaty on European Union, 7 February 1992, 1992 O.J. (C 191).

25 "RESOLVED to achieve the strengthening and the convergence of their economies and to establish an economic and monetary union including, in accordance with the provisions of this Treaty, a single and stable currency [...]"

26 Art. 3a of the TEC (as amended) read as follows:

1. For the purposes set out in Article 2, the activities of the Member States and the Community shall include, as provided in this Treaty and in accordance with the timetable set out therein, the adoption of an economic policy which is based on the close coordination of Member States' economic policies, on the internal 
Report leading up to the adoption of a single currency, with the primary objective being to "maintain price stability". Without prejudice to this objective, the Eurosystem ${ }^{27}$ was also to "support the general economic policies in the Community". In other words, Community economic policies, although subject to coordination, would remain within the competence of each Member State; conversely, competence in the field of monetary policy would be transferred to Community institutions. The overarching guiding principles were to sustain price stability, ensure sound public finances and maintain a sustainable balance of payments. ${ }^{28}$

A new title was added to the Treaty of Rome called "Economic and monetary policy", which included Arts. 102a-109m. As mentioned above, this new title stipulated that "Member States shall conduct their [emphasis added] economic policies with a view to contributing to the achievement of the objectives of the Community". In that regard, however, it is important to point out that Member States were not entirely free to draw up their economic policies: though in principle they had competence in the field of economic policy, they were nonetheless required by the TEC (and previously by the TEEC) to respect obligations relating to the internal market (freedom of establishment, free movement of capital, etc.) and European competition policy (on State aid).

market and on the definition of common objectives, and conducted in accordance with the principle of an open market economy with free competition.

2. Concurrently with the foregoing, and as provided in this Treaty and in accordance with the timetable and the procedures set out therein, these activities shall include the irrevocable fixing of exchange rates leading to the introduction of a single currency, the ECU, and the definition and conduct of a single monetary policy and exchange rate policy the primary objective of both of which shall be to maintain price stability and, without prejudice to this objective, to support the general economic policies in the Community, in accordance with the principle of an open market economy with free competition.

3. These activities of the Member States and the Community shall entail compliance with the following guiding principles: stable prices, sound public finances and monetary conditions and a sustainable balance of payments.

27 The Eurosystem consists of the ECB and the national central banks of countries that have adopted the euro, whereas the ESCB consists of the ECB and the national central banks of all EU Member States, regardless of whether they have adopted the euro.

28 The implicit assumption was that decentralised coordination was enough to avoid market failures in fiscal policy: notably the accumulation of persistent balance of payments imbalances of such an extent that, to be resolved, they would require external intervention. The idea was that if Member States simply respected sound public finance rules within the single market, and followed country-specific recommendations, they would be able to avoid imbalances leading to a balance of payments crisis in the euro area. The sudden stop in capital flows at the end of 2008 proved this wrong and exposed the imperfection of EMU's institutional design. 
Additionally, the new provisions on economic and monetary union expressly stated that the Member States' economic policies were to be viewed as a matter of common concern and coordinated within the Council. Specifically, the European Council was to come to a conclusion on broad guidelines for Member States' economic policies, which the Council would then act on by adopting a recommendation that set out those guidelines. The Council would subsequently monitor economic developments in each Member State and ensure that they were consistent with the established guidelines. If it was determined that a Member State's economic policy failed to adhere to the guidelines or that it risked jeopardising the proper functioning of economic and monetary union, the Council would be entitled to make relevant recommendations. The Treaty envisaged appropriate measures if a Member State was faced with severe difficulties in the supply of certain products; the Council could also grant financial assistance to a Member State facing severe difficulties beyond its control (Art. 103a). Art. 104c stipulated that Member States were to avoid excessive government deficits; the same article also tasked the Commission with monitoring the development of each Member State's budgetary situation. Specifically, budgetary compliance was to be assessed based on two criteria: the ratio of deficit to gross domestic product (GDP) and the ratio of government debt to GDP. The reference values (specified in Protocol No. 12) were $3 \%$ for the ratio of the planned or actual government deficit to GDP, and $60 \%$ for the ratio of government debt to GDP. The TEC set out a detailed procedure in this regard - and if a Member State failed to comply with the Council's recommendations, it could be forced to make a non-interest bearing deposit of an appropriate size and pay significant fines.

The Maastricht Treaty also established the institutional framework for Community monetary policy. It took inspiration from the prevailing theoretical model at the time - which had first taken root in the 1970s with the end of the gold standard - according to which the ECB and all the national central banks that made up the ESCB had to be completely independent, i.e., free from any form of political pressure. This would reassure markets that Europe's monetary policy aimed exclusively at maintaining price stability and was not subject to the influence of Member State governments, which by definition were more concerned with unemployment rates, economic policy implications and upcoming elections than inflation rates. The Maastricht Treaty was thus designed to address the "time-consistency" problem (i.e., to ensure the credibility of the ECB's commitment to pursuing its monetary policy also in the future): it clearly stated that the ESCB's and ECB's primary objective was price stability and set out their tasks and responsibilities. The ECB would have the exclusive right to authorise the issue of bank notes within the Community.

Lastly, the Maastricht Treaty included transitional provisions for the second stage of economic and monetary union and in preparation for the third stage. 
Convergence was to be assessed by referring to the following criteria: (i) an inflation rate close to that of the three best performing Member States in terms of price stability; (ii) sustainability of the government financial position (i.e., no excessive deficit); (iii) a stable exchange rate for at least two years; and (iv) long-term interest rate levels that showed the durability of the convergence. The Council would then assess each Member State to determine whether it met the criteria to adopt a single currency.

These convergence criteria were detailed in Protocol No. 13, ${ }^{29}$ though Art. 6 of the protocol allowed the Council - acting unanimously on a proposal from the Commission and after consulting the European Parliament and the ECB to adopt provisions to lay down further details of the criteria, which would then replace the protocol. In this way, the rigidity of the rules was dampened, and the TEC would not have to be amended in the future to accommodate changes to the convergence criteria. Art. 104c(14) of the TEC - now Art. 126 of the Treaty on the Functioning of the European Union (TFEU) - set out a similar provision concerning Protocol No. 12 (on the excessive deficit procedure).

Lastly, it is worth highlighting the difference in drafting technique between the Maastricht Treaty's provisions on economic and monetary union and the other amendments it introduced to the TEC - a consequence of the fact that two intergovernmental conferences were called to negotiate different provisions relating to economic and monetary union and political union, respectively. Indeed, the other TEC amendments were consistent with the treaty's previous language, whereas the provisions on economic and monetary union were quite different: e.g., they went into extreme detail, laid down stringent obligations for Member States, had few legal bases underlying the general principles, left

29 The criterion on price stability means that a Member State has a price performance that is sustainable and an average rate of inflation, over a period of one year before the examination, that does not exceed by more than one-and-a-half percentage points that of, at most, the three best performing Member States in terms of price stability; the criterion on the government budgetary position means that at the time of the examination the Member State is not the subject of a Council decision that an excessive deficit exists; the criterion on participation in the exchange-rate mechanism of the EMS means that a Member State has respected the normal fluctuation margins provided for by the exchange-rate mechanism without severe tensions for at least the last two years before the examination; and the criterion on the convergence of interest rates means that, over a period of one year before the examination, a Member State has had an average nominal long-term interest rate that does not exceed by more than two percentage points that of, at most, the three best performing Member States in terms of price stability. 
much room for non-binding acts (such as guidelines and recommendations), and established quantitative objectives. ${ }^{30}$

\subsection{THE MEMBER STATES WITH A DEROGATION}

During the negotiations leading up to the Maastricht Treaty, the United Kingdom and Denmark were given the possibility of opting out of the third stage of economic and monetary union. These derogations, specifically requested by the two countries, were set out in Protocols Nos. 25 and 26, respectively; however, the Conclusions from the Copenhagen European Council of June 1993 made it clear that these were special derogations that could not be extended to any other countries. Indeed, in setting out the membership requirements for Central and Eastern European countries, the European Council specified that "Membership presupposes the candidate's ability to take on the obligations of membership including adherence to the aims of political, economic and monetary union". ${ }^{31}$

Apart from these two exceptions, all Member States were required to adopt the single currency at some point. Any Member States that did not immediately meet the convergence criteria under Art. 109j of the TEC upon transitioning to the third stage of economic and monetary union were considered "Member States with a derogation" and would have to adopt the single currency at a later date. Sweden, however, did not join the Exchange Rate Mechanism II (ERM II) - and in 2003, it held a non-binding referendum in which a clear majority voted against adopting the euro. Nonetheless, this conduct was tolerated, and Sweden was allowed to retain the status of Member State with a derogation for

30 In certain respects, the provisions on economic and monetary union could be likened to those on employment policy introduced by the Treaty of Amsterdam, which require Member States to coordinate their policies and to develop a coordinated strategy for employment that takes into account Council guidelines and recommendations.

31 European Council in Copenhagen 21-22 June 1993, Conclusions of the Presidency (SN 180/1/93/ REV 1):

The European Council today agreed that the associated countries in Central and Eastern Europe that so desire shall become members of the European Union. Accession will take place as soon as an associated country is able to assume the obligations of membership by satisfying the economic and political conditions required.

Membership requires that the candidate country has achieved stability of institutions guaranteeing democracy, the rule of law, human rights and respect for and protection of minorities, the existence of a functioning market economy as well as the capacity to cope with competitive pressure and market forces within the Union. Membership presupposes the candidate's ability to take on the obligations of membership including adherence to the aims of political, economic and monetary union. 
political reasons, given that it had not met the legal criteria set out in the TEC. ${ }^{32}$ In any case, all Member States with a derogation are subject to periodic checks to determine whether they have met the convergence criteria.

It is worth repeating that all Member States are required to adopt the euro after transitioning to the third stage - not just the Member States that were able to adopt it immediately. The TEC even listed the provisions that did not apply to Member States with a derogation, ${ }^{33}$ specified that those States' voting rights are suspended for Council decisions referred to in those provisions, and referenced the fact that these States (and their national central banks) are excluded from rights and obligations within the ESCB. Furthermore, the TEC also clarified ${ }^{34}$ that Member States with a derogation can benefit from the measures available under Art. 109h (difficulties or serious threat of difficulties concerning the balance of payments) ${ }^{35}$ and Art. 109i (sudden crisis in the balance of payments).

Though these provisions make differentiated integration possible, that integration cannot be likened to enhanced cooperation (the regulation of which - first introduced by the Treaty of Amsterdam, subsequently broadened by the Treaty of Nice, and ultimately amended by the Treaty of Lisbon - is now set out in Art. 20 of the TEU). First, monetary policy is an area of exclusive competence, whereas enhanced cooperation is envisaged only in areas of shared competence. ${ }^{36}$ Second, it is not the Member States that want a multi-speed Europe in this case but rather the Treaty itself that requires - in the interest of

32 The Commission's 2020 convergence report - in which the Commission provides its assessment of the progress non-euro area Member States have made towards adopting the euro - states that legislation in Sweden is not fully compatible with the compliance duty under Art. 131 of the TFEU (in particular in the fields of independence of the central bank, prohibition of monetary financing and central bank integration into the ESCB) and that Sweden does not fulfil the exchange rate criterion because it is not a member of ERM II; see European Commission, Report from the Commission to the European Parliament and the Council, Convergence Report 2020, COM (2020) 237 final (10 June 2020).

33 Art. $109 \mathrm{k}(3)$ read as follows:

A derogation referred to in paragraph 1 shall entail that the following Articles do not apply to the Member State concerned: Articles 104c (9) and (11), 105 (1), (2), (3) and (5), 105a, 108a, 109, and 109a (2)(b). The exclusion of such a Member State and its national central bank from rights and obligations within the ESCB is laid down in Chapter IX of the Statute of the ESCB.

34 Art. 109k(6): "Articles 109h and 109i shall continue to apply to a Member State with a derogation."

35 See the current provisions in Art. 143 of the TFEU, examined in Chapter 4, section 4.1.

36 Giulia Rossolillo, Cooperazione rafforzata e unione economica e monetaria: modelli di flessibilità a confronto, 97 RIVISTA DI DIRITTO INTERNAZIONALE 325 (2014). 
monetary stability - fulfilment of the convergence criteria before a Member State can adopt the single currency. Lastly, as mentioned above, the status of Member States with a derogation is only temporary. All EU Member States (except for those indicated above) must ultimately join the euro area. Monetary unification is indeed one of the fundamental pillars of European integration not only because of its economic impact but also because of its geopolitical impact. It would thus be unacceptable to have a Europe "à la carte" in this area.

\subsection{THE ESTABLISHMENT OF ECONOMIC AND MONETARY UNION}

When the Maastricht Treaty came into force, it paved the way for economic and monetary union (EMU). The European Monetary Institute (EMI) ${ }^{37}$ was established on 1 January 1994: its objectives included strengthening cooperation among European central banks, coordinating monetary policies and carrying out the preparatory work needed before the third stage could be implemented.

The following year, the European Council decided to name the single currency the "euro" and established the timetable of events ("changeover scenario") leading up to transition. ${ }^{38}$

In June of 1997, the European Council adopted the Stability and Growth Pact, which will be examined in depth in Chapter 2.

On 3 May 1998, the Council - meeting in the composition of the Heads of State or of Government ${ }^{39}$ - unanimously declared that 11 countries (Austria, Belgium, Finland, France, Germany, Ireland, Italy, Luxembourg, the Netherlands, Portugal and Spain $)^{40}$ had fulfilled the necessary conditions for the adoption of the euro, which would take place on 1 January $1999 .^{41}$ Interestingly, the criterion regarding the sustainability of a Member State's government financial position was considered fulfilled if the Member State was not the subject of a Council decision declaring that an excessive deficit existed. In that regard, one of the fundamental

\footnotetext{
37 Art. 109f and Protocol on the Statute of the European Monetary Institute.

38 Madrid European Council, 14-15 December 1995, Presidency Conclusions, Bulletin of the European Union, No 12, at 10 (1995).

39 Although it met in this composition, the body that was called on to make this decision was the Council, not the European Council (which was not yet an EU institution). Given the historical importance of the decision, it was decided to make a special exception, i.e., to indicate the composition of this meeting of the Council in primary legislation.

40 The situations of Denmark and the United Kingdom were not examined as they were both exempted by an "opt-out" arrangement. Greece and Sweden did not meet the conditions to move on to the third stage.

${ }^{41}$ Council Decision 98/317/EC on the fulfilment of the necessary conditions for the adoption of the single currency on 1 January 1999, 1998 O.J. (L 139) 30.
} 
requirements for a Member State was that its ratio of government deficit to GDP be lower than the reference value of 3\%. Conversely, more leeway was allowed when the Council assessed the ratio of government debt to GDP: indeed, only three Member States' ratios were under the reference value of $60 \%$. It was thus clear right from admission to the third stage that more weight was given to the deficit reference value than the debt reference value. ${ }^{42}$ And this disparate treatment was not just limited to the initial period - it continued over time. Therefore, even a debt-to-GDP ratio that was well over the Maastricht Treaty's reference value was tolerated if it was considered under control and sufficiently diminishing. Conceptually, no grounds existed to treat the two criteria differently. This choice was thus presumably made for pragmatic reasons: it would have been difficult to remedy the expansionary policies of the past, whereas by bringing down deficits (assuming the growth in GDP typical of those years), debt levels were expected to fall over time, or at least to be kept under control. However, the financial crisis would end up showing how unfounded those assumptions were: in the span of only a few months, government debts skyrocketed (just think of the huge costs incurred to recapitalise banking systems). Yet it would not be until 2019 when, for the first (and, to date, only) time, the Commission threatened to launch a debt-based EDP, against Italy. ${ }^{43}$

Again on 3 May 1998, a regulation on the introduction of the euro ${ }^{44}$ was enacted, and the bilateral central rates of the currencies to be used in determining the irrevocable conversion rates for the euro were announced. ${ }^{45}$ On the same date, the Council recommended members for appointment to the ECB's Executive Board. ${ }^{46}$

On 25 May 1998, the President, Vice-President and the other members of the ECB's Executive Board were appointed, and the ECB was officially established on 1 June. At the same time, the EMI - having fulfilled its role - went into liquidation.

On 31 December 1998, the Council fixed the irrevocable conversion rates between the 11 participating currencies and the euro, ${ }^{47}$ and on 1 January 1999 the

42 E.g., the 1997 Resolution of the European Council on the Stability and Growth Pact (see Chapter 2, section 2.1) focuses only on excessive deficits and makes no mention of the other reference value.

43 See Chapter 7, section 7.4.

44 Council Regulation (EC) No 974/98 of 3 May 1998 on the introduction of the euro, 1998 O.J. (L 139) 1.

45 Joint Communiqué of 3 May 1998 by the Ministers and Central Bank Governors of the Member States adopting the euro as their single currency, the Commission and the European Monetary Institute on the determination of the irrevocable conversion rates for the euro, 1998 O.J. (C 160) 1.

46 Council Recommendation 98/318/EC of 3 May 1998 on the appointments of the President, the Vice-President and the other members of the Executive Board of the European Central Bank, 1998 O.J. (L 139) 36.

47 Council Regulation (EC) No 2866/98 of 31 December 1998 on the conversion rates between the euro and the currencies of the Member States adopting the euro, 1998 O.J. (L 
third stage began: a single currency and a single monetary policy under the aegis of the ECB. The Member States that did not adopt the euro (either because they opted out, as was the case with Denmark and the United Kingdom, or because they failed to fulfil the necessary conditions, as was the case with Greece and Sweden) were subject to the rules applicable to "Member States with a derogation".

The euro was used as scriptural money until 1 January 2002, when euro notes and coins became legal tender and replaced national currencies.

Since 2004, 15 new countries have become members of the European Union in three different periods. The accession treaties stipulate that each new Member State is to be admitted as a "Member State with a derogation". ${ }^{48}$

As mentioned above, these States may be admitted to the third stage of EMU through a Council decision, in accordance with the procedure set out in Art. 109k, para. 2 of the Maastricht Treaty (now Art. 140 of the TFEU). Every two years - or at the request of the Member State concerned - the Commission and the ECB must assess the progress made by Member States with a derogation in fulfilling their obligations regarding the achievement of EMU. If the assessment is positive, the Commission submits a proposal to the Council to abrogate the derogation and allow the Member State to adopt the euro. The assessment is based on the same criteria used in 1998. Since 1 January 1999, the ERM II exchange rate mechanism has provided a framework for assessing whether a Member State with a derogation meets the exchange rate criterion for adoption of the euro. ${ }^{49}$

359) 1. The conversion rates adopted were determined based on the then-current ERM bilateral central rates (market rates had started to align with the central parities in the previous months, indicating that the markets considered them reasonable).

48 See Art. 4 of the Act concerning the conditions of accession of the Czech Republic, the Republic of Estonia, the Republic of Cyprus, the Republic of Latvia, the Republic of Lithuania, the Republic of Hungary, the Republic of Malta, the Republic of Poland, the Republic of Slovenia and the Slovak Republic and the adjustments to the Treaties on which the European Union is founded, 2003 O.J. (L 236) 33: "Each of the new Member States shall participate in Economic and Monetary Union from the date of accession as a Member State with a derogation within the meaning of Article 122 of the TEC." See also Art. 5 of the Act concerning the conditions of accession of the Republic of Bulgaria and Romania and the adjustments to the treaties on which the European Union is founded, 2005 O.J. (L 157) 203), and Art. 5 of the Act concerning the conditions of accession of the Republic of Croatia and the adjustments to the Treaty on European Union, the Treaty on the Functioning of the European Union and the Treaty establishing the European Atomic Energy Community, 2012 O.J. (L 122) 21.

49 Resolution of the European Council on the establishment of an exchange-rate mechanism in the third stage of economic and monetary union, Amsterdam, 16 June 1997, 1997 O.J. (C 236) 5; Agreement of 1 September 1998 between the European Central Bank and the national central banks of the Member States outside the euro area laying down the operating procedures for an exchange rate mechanism in stage three of Economic and Monetary Union, 1998 O.J. (C 345) 6. 
Currently, ERM II includes the currencies of Bulgaria, Croatia and Denmark. The Bulgarian lev joined ERM II on 10 July 2020 and observes a central rate of 1.95583 to the euro. Bulgaria also unilaterally committed to continuing its currency board arrangement within the ERM II. The Croatian kuna joined ERM II on 10 July 2020 and observes a central rate of 7.53450 to the euro, with a standard fluctuation band of $\pm 15 \%$. The Danish kroner joined ERM II on 1 January 1999 and observes a central rate of 7.46038 to the euro, with a narrow fluctuation band of $\pm 2.25 \%$.

Over time, the eurozone has expanded from its original 11 countries to its current 19 countries, with Greece ${ }^{50}$ joining in 2001, Slovenia ${ }^{51}$ in 2007, Cyprus $^{52}$ and Malta ${ }^{53}$ in 2008, Slovakia ${ }^{54}$ in 2009, Estonia ${ }^{55}$ in 2011, Latvia ${ }^{56}$ in 2014 and Lithuania ${ }^{57}$ in 2015.

50 Council Decision 2000/427/EC of 19 June 2000 in accordance with Article 122(2) of the Treaty on the adoption by Greece of the single currency on 1 January 2001, 2000 O.J. (L 167) 19; Council Regulation (EC) No 1478/2000 of 19 June 2000 amending Regulation (EC) No 2866/98 on the conversion rates between the euro and the currencies of the Member States adopting the euro, 2000 O.J. (L 167) 1.

51 Council Decision 2006/495/EC of 11 July 2006 in accordance with Article 122(2) of the Treaty on the adoption by Slovenia of the single currency on 1 January 2007, 2006 O.J. (L 195) 25; Council Regulation (EC) No 1086/2006 of 11 July 2006 amending Regulation (EC) No 2866/98 on the conversion rates between the euro and the currencies of the Member States adopting the euro, 2006 O.J. (L 195) 1.

52 Council Decision 2007/503/EC of 10 July 2007 in accordance with Article 122(2) of the Treaty on the adoption by Cyprus of the single currency on 1 January 2008, 2007 O.J. (L 186) 29; Council Regulation (EC) No 1135/2007 of 10 July 2007 amending Regulation (EC) No 2866/98 as regards the conversion rate to the euro for Cyprus, 2007 O.J. (L 256) 2.

53 Council Decision 2007/504/EC of 10 July 2007 in accordance with Article 122(2) of the Treaty on the adoption by Malta of the single currency on 1 January 2008, 2007 O.J. (L 186) 32; Council Regulation (EC) No 1134/2007 of 10 July 2007 amending Regulation (EC) No 2866/98 as regards the conversion rate to the euro for Malta, 2007 O.J. (L 256) 1.

54 Council Decision 2008/608/EC of 8 July 2008 in accordance with Article 122(2) of the Treaty on the adoption by Slovakia of the single currency on 1 January 2009, 2008 O.J. (L 195) 24; Council Regulation (EC) No 694/2008 of 8 July 2008 amending Regulation (EC) No 2866/98 as regards the conversion rate to the euro for Slovakia, 2008 O.J. (L 195) 3.

55 Council Decision 2010/416/EU of 13 July 2010 in accordance with Article 140(2) of the Treaty on the adoption by Estonia of the euro on 1 January 2011, 2010 O.J. (L 196) 24; Council Regulation (EU) No 671/2010 of 13 July 2010 amending Regulation (EC) No 2866/98 as regards the conversion rate to the euro for Estonia, 2010 O.J. (L 196) 4.

56 Council Decision 2013/387/EU of 9 July 2013 on the adoption by Latvia of the euro on 1 January 2014, 2013 O.J. (L 195) 24; Council Regulation (EU) No 870/2013 of 9 July 2013 amending Regulation (EC) No 2866/98 as regards the conversion rate to the euro for Latvia, 2013 O.J. (L 243) 1.

57 Council Decision 2014/509/EU of 23 July 2014 on the adoption by Lithuania of the euro on 1 January 2015, 2014 O.J. (L 228) 29; Council Regulation (EU) No 
EMU's regulatory framework has remained largely unchanged. However, the Treaty of Lisbon - picking up where the (unsuccessful) Treaty establishing a Constitution for Europe left off - introduced several small changes to the regulations governing EMU. Indeed, the Treaty of Lisbon allocated areas of competence to the Union by category (Arts. 2-6 of the TFEU) in order to better define its scope of power and its relationships with Member States. However, in contrast to the internal market or the area of freedom, security and justice, EMU does not fall within a single area of competence: the Union has exclusive competence when it comes to monetary policy for Member States whose currency is the euro (Art. 3(1)(c) of the TFEU), but Member States must coordinate their economic policies within the Union in accordance with the broad guidelines adopted by the Council for those policies (Art. 5 of the TFEU). Thus, the Union's competence with respect to EMU does not fall squarely within any of the areas listed under the above articles - rather, it is one of its own.

Some of the amendments introduced by the Treaty of Lisbon simply aimed to tighten up the language of the earlier version of the TEC, in order to take recent changes into account (e.g., the co-decision procedure - reference to which had remained in the part of the TEC dealing with EMU - was replaced by the ordinary legislative procedure for cases under Art. 121(6) of the TFEU and by special legislative procedures for other cases). Other amendments were needed to render the transitional provisions originally utilised for the initial achievement of EMU applicable to the Member States with a derogation that, in due course, were to adopt the euro. The most significant change was probably the introduction of Chapter 4, entitled "Provisions specific to Member States whose currency is the euro". Art. 136 allows the Council to use the procedures under Art. 121 (on the coordination of economic policies) and Art. 126 (on excessive deficit procedures) ${ }^{58}$ to adopt measures specific to Member States whose currency is the euro. This article thus allows decisions to be made that are binding on a group of (i.e., not all) Member States in accordance with a different procedure from that envisaged for enhanced cooperation. Indeed, in EMU, the Council's ability to adopt measures specific to euro-area Member States is made possible by virtue of primary law - and not through a decision to authorise enhanced cooperation under Art. 329 of the TFEU.

The sovereign debt crisis that struck Member States had a significant impact on the governance of the euro area. Indeed, it laid bare some gaps in the

$851 / 2014$ of 23 July 2014 amending Regulation (EC) No 2866/98 as regards the conversion rate to the euro for Lithuania, 2014 O.J. (L 233) 21.

58 The Council may not use the powers set out in Art. 136 to adopt measures under Art. 126(14). 
original regulatory framework envisaged by the TFEU, which did not contain (perhaps intentionally, so as not to create moral hazard) solutions or mechanisms to assist Member States that no longer had the budgetary capacity to finance themselves or could not obtain financing from market sources. These gaps were filled not through amendments to the TFEU but through secondary legislation and international agreements between Member States. As a result, the European Council has seen its role strengthened (including through the establishment of the Euro Summit) while the European Parliament has seen itself marginalised; and the relationship between the Commission and Member States has moved away from the kind of cooperation envisaged by the TFEU while the ECB has intruded more and more into economic policies.

\section{SELECTED BIBLIOGRAPHY}

André Szász, The Monetary Union Debate, 7 Common Mкт. L. Rev. 407 (1970)

Dominique Carreau, La Communauté économique européenne face aux problèmes monétaires, 7 REVUE TRIMESTRIELLE DE DROIT EUROPÉEN 586 (1971)

Harry G. Johnson, Problems of European Monetary Union, in 5 J. World Trade L. $377(1971)$

Horst Ungerer, A Concise History of European Monetary Integration: from EPU то EMU (1997)

Hugo J. Hahn, The Stability Pact for European Monetary Union: Compliance with Deficit Limit as Constant Legal Duty, 35 Coмmon Mкт. L. Rev. 77 (1998)

Matthias J. Herdegen, Price Stability and Budgetary Restraints in the Economic and Monetary Union: The Law as Guardian of Economic Wisdom, 35 СоммоN Мкт. L. Rev. 9 (1998)

Jean-Victor Louis, A Legal and Institutional Approach for Building a Monetary Union, 35 Common MkT. L. Rev. 33 (1998)

Susanna CAFARo, Unione monetaria E COORDINAMENTO DELle POLITICHE ECONOMICHE: IL DIFFICILE EQUILIBRIO TRA MODELLI ANTAGONISTI DI INTEGRAZIONE EUROPEA (2001)

Fritz Breuss, Gerhard Fink \& Stefan Griller (eds.), Institutional, Legal and ECONOMIC ASPECTS OF THE EMU (2003)

Christoph A. Stumpf, The Introduction of the Euro to States and Territories outside of the European Union, 28 Eur. L. Rev. 283 (2003)

Jean-Victor Louis, The Economic and Monetary Union: Law and Institutions, 41 Common MKt. L. Rev. 575 (2004)

James D. Savage, Making the EMU: the Politics of Budgetary Surveillance AND THE ENFORCEMENT OF MAASTRICHT (2005)

Gian Luigi Tosato \& Riccardo Basso, L'unione eConomica e monetaria: aspetTi GIURIDICI E ISTITUZIONALI: STUDIO INTRODUTTIVO E MATERIALI DI BASE (2nd ed. 2007)

Dermott McCann, The Political Economy of the European Union: An Institutionalist Perspective (2010)

Constanze Semmelmann, The European Union's Economic Constitution under the Lisbon Treaty: Soul-Searching Shifts the Focus to Procedure, 35 Eur. L. Rev. 516 (2010) 
Giulia Rossolillo, Cooperazione rafforzata e unione economica e monetaria: modelli di flessibilità a confronto, 97 RIVISTA DI DIRITTO INTERNAZIONALE 325 (2014)

Paolo Ponzano, L'intégration différenciée au sein de l'Union européenne et la "constitutionnalisation” de la zone Euro, REVUE DU DROIT DE L'UNION EUROPÉENNE 179 (2015) 